\title{
In Vitro and In Silico Anti-Breast Cancer Analysis of Bioactive Metabolites of Bacillus subtilis Isolated From Soil
}

Ram Kumar A ${ }^{1}$, Rajagopal. $\mathrm{K}^{1}$, Meenambiga $\mathrm{SS}^{2}$ and Kumaresan $\mathrm{S}^{1^{*}}$

${ }^{1}$ PG and Research Department of Plant Biology and Plant Biotechnology, Ramakrishna Mission Vivekananda College (Affiliated to University of Madras), Mylapore, Chennai-600004, India

${ }^{2}$ Department of Bio-Engineering, School of Engineering, VISTAS, Pallavaram, Chennai-600117, India

DOI: $\underline{10.36348 / \mathrm{sjpm} .2020 . \mathrm{v} 05 \mathrm{i} 04.006}$

| Received: 13.03.2020 | Accepted: 21.03.2020 | Published: 30.04 .2020

*Corresponding author: S. Kumaresan

\section{Abstract}

Objective: Breast cancer is the most common cancer faced by women around the worldwide. The Estrogen receptor alpha $(\mathrm{ER} \alpha)$ has been playing a major role in the stimulation of breast cancer. The present study aims to identify the anticancer activity of crude extract of Bacillus subtilis against breast cancer cell line by in vitro and in silico methods. Methods: The soil samples were collected from different regions in the reserve forests of Western Ghats of Nilgiris district in Tamil Nadu, India. Isolation of bacterial strain from the collected soil samples was performed by serial dilution method. Identification of bacterial strain was done by $16 \mathrm{~S}$ rRNA sequencing analysis. The anti-cancer potential of crude extract of bacterial strain was tested against breast cancer cell line (MCF-7) by MTT assay. Further, the bioactive compounds found in the crude extract of bacterial strain was identified by GC-MS and the identified compounds was subjected to in silico docking studies against the targeted breast cancer protein Estrogen receptor alpha (ER $\alpha)$. Result: The bacterial strain isolated from the soil sample by serial dilution method was identified as Bacillus subtilis by $16 \mathrm{~S}$ rRNA analysis. In vitro anti-breast cancer analysis of crude extract of Bacillus subtilis showed potential activity against MCF-7 breast cancer cell line with the IC50 value of $100 \mu \mathrm{g} / \mathrm{ml}$. The GC-MS analysis of the ethyl acetate extract of Bacillus subtilis showed twenty-six bioactive compounds. The compound Metaraminol showed maximum docking score $-7.27 \mathrm{Kcal} / \mathrm{mol}$ against the target protein. Conclusion: The crude extract of soil bacterium showed potent anti-cancer activity against breast cancer cell lines. Further, the bioactive compounds showed good binding interactions with the virulence factor of breast cancer. Thus, the compounds of soil bacterium Bacillus subtilis could effectively used as leads for developing drugs against breast cancer.

Keywords: Bacillus subtilis, Breast cancer, Estrogen receptor alpha (ER $\alpha)$, GC-MS, Western Ghats.

Copyright @ 2020: This is an open-access article distributed under the terms of the Creative Commons Attribution license which permits unrestricted use, distribution, and reproduction in any medium for non-commercial use (NonCommercial, or CC-BY-NC) provided the original author and sources are credited.

\section{INTRODUCTION}

Cancer is the second leading cause of death globally with 8.8 million cancer-related deaths in 2015 . Breast cancer is the most common cancer among women worldwide and the highest in women between 44 and 55 years of age. Although equally prevalent in developed and developing countries, breast cancer survival rates are higher (80\%) in developed countries when compared to developing countries (less than 60\%) and underdeveloped countries (less than 40\%) [1]. The Estrogen receptors are the major prognostic markers used to identify tumors in breast tissue [2]. Estrogen receptor positive cancer is the most frequent subtype representing more than $70 \%$ of breast cancer. The Estrogen receptor consists of two subtypes namely Estrogen receptor alpha $(\mathrm{ER} \alpha)$ and Estrogen receptor beta $(\operatorname{ER} \beta)$ that have different affinities to estrogen. The
Estrogen receptor alpha $(\mathrm{ER} \alpha)$ is an activated ligand by a transcriptional regulator which is the main regulator of differentiation and proliferation of breast cells. Additionally, the Estrogen receptor $\alpha(\mathrm{ER} \alpha)$ plays an important role in the development and progression of dependent hormonal type breast cancer [3].

Soil is a highly complex environment possessing the highest microbial diversity on earth, which are important components of the biogeochemical cycles in terrestrial ecosystems [4-6]. In particular, soil bacteria is the key contributor to nutrient cycling and productivity in ecosystem processes, as it is the most abundant and diverse microbial community [7]. Besides, soil bacteria are not only the key factor to influence soil nutrients decomposition and mineralization $[8,9]$. But it is also the main source of secondary metabolites, which have different 
physiochemical biological properties and then in turn affect soil environment and plant growth [10,4]. They produce unique biologically active metabolites, novel products like antibiotics, vaccines, steroids as well as other therapeutically useful compounds. A huge number of currently used antibiotics including erythromycin, streptomycin, rifamycin, and gentamycin, are all products isolated from soil bacteria [11, 12]. Members of the genus Bacillus are commonly found in soil and produce a variety of bioactive metabolites that are effective against many pathogenic microorganisms [13]. In particular, B. amyloliquefaciens and B. subtilis isolated from soil produce a variety of antibiotics with antimicrobial, anti-inflammatory, anti-viral, and anticancer properties $[14,15]$. The primary aim of the present study is to identify the anticancer potential of crude extract of bacterial strain against breast cancer cell line (MCF-7) by in vitro analysis and the secondary aim is to identify the potent anti-breast cancer compound from the bacterial crude extract using in silico studies.

\section{MATERIALS AND METHODS Isolation of bacteria from soil sample}

The soil samples were collected from Nilgiri district (Lat $11^{0} 08^{\prime}$ to $13^{\circ} 37^{\prime} \mathrm{N}$, Long $77^{\circ} 27^{\prime}$ to $80^{\circ} 4^{\prime}$ E) Western Ghats, Tamil Nadu, India. Isolation and enumeration of bacteria were performed by serial dilution method ${ }^{18}$. Briefly, one gram of soil was suspended in $9 \mathrm{~mL}$ of sterile double distilled water. The dilution was carried out up to $10^{-5}$ dilutions. Aliquots $(0.1 \mathrm{~mL})$ of $10^{-2}, 10^{-3}, 10^{-4}$, and $10^{-5}$ were spread on the Nutrient Agar (NA) medium containing (g/L) Peptone 5.0; $\mathrm{NaCl} 5.0$; Beef extract 1.5; Yeast extract 1.5, Agar Agar 15.0 and $\mathrm{pH}$ 7. The plates were incubated at $37^{\circ} \mathrm{C}$ for 2 days and bacterial colonies were purified by repeated streaking. The purified colonies were stored at $4^{\circ} \mathrm{C}$ for further analysis.

\section{Molecular identification of bacterial isolate Isolation of genomic DNA}

The genomic DNA of active strain was isolated using NucleoSpin ${ }^{\circledR}$ Tissue Kit (MachereyNagel). Briefly, the pure bacterial culture was taken in a microcentrifuge tube. $180 \mu \mathrm{l}$ of T1 buffer and $25 \mu \mathrm{l}$ of proteinase $\mathrm{K}$ was added and incubated at $56{ }^{\circ} \mathrm{C}$ in a water bath until it were completely lysed. After lysis, 5 $\mu \mathrm{l}$ of RNase A $(100 \mathrm{mg} / \mathrm{ml})$ solution was added and incubated at room temperature for 5 minutes. Then 200 $\mu \mathrm{l}$ of B3 buffer was added and incubated at $70^{\circ} \mathrm{C}$ for 10 minutes. $210 \mu \mathrm{l}$ of $100 \%$ ethanol was added and mixed thoroughly using vortex mixturte. The mixture was pipetted into NucleoSpin ${ }^{\circledR}$ Tissue column placed in a 2 $\mathrm{ml}$ collection tube and centrifuged at $11,000 \mathrm{rpm}$ for one minute at room temperature. The NucleoSpin ${ }^{\circledR}$ Tissue column was transferred to a new $2 \mathrm{ml}$ tube and washed with $500 \mu \mathrm{l}$ of BW buffer. Wash step was repeated using $600 \mu \mathrm{l}$ of B5 buffer. After washing the NucleoSpin ${ }^{\circledR}$ Tissue column was placed in a clean 1.5 $\mathrm{ml}$ tube and DNA was eluted out using $50 \mu \mathrm{l}$ of BE buffer. Finaly the DNA was eluted by centrifuging at $11,000 \mathrm{rpm}$ for one minute.

\section{$16 S$ rRNA analysis \\ The primers 16S-RS-Forward- \\ CAGGCCTAACACATGCAAGTC and 16S-RS-}

Reverse- GGGCGGWGTGTACAAGGC $\left(5^{\prime} \rightarrow 3^{\prime}\right)$ were used to amplify $16 \mathrm{~S}$ ribosomal sequences from genomic DNA were carried out in a PCR thermal cycler (GeneAmp PCR System 9700, Applied Biosystems). Sequencing reaction was done in a PCR thermal cycler (GeneAmp PCR System 9700, Applied Biosystems) using the BigDye Terminator v3.1 Cycle sequencing Kit (Applied Biosystems, USA). The sequence quality was checked using Sequence Scanner Software v1 (Applied Biosystems). Sequence alignment and required editing of the obtained sequences were carried out using Geneious Pro v5.6 [16].

\section{Database searching and phylogenetic analysis}

The obtained nucleotide sequence was compared with sequence details of other organisms in NCBI using BLAST tool (http://www.ncbi.nlm.nih.gov/BLAST). A phylogenetic tree was constructed based on the Neighbor-joining method using MEGA (version 4.0) software [17].

\section{Cultivation and extraction of bacterial metabolites}

The isolated bacterial cultures inoculated in the $250 \mathrm{ml}$ of conical flask containing $100 \mathrm{ml}$ of Nutrient Broth medium (NB). After the, $72 \mathrm{hrs}$ of incubation at 130rpm the fermented culture extracted with an equal volume of ethyl acetate (1:1). The crude extract concentrated and stored at $4^{\circ} \mathrm{C}$ for further studies.

\section{Cell line}

Human breast cancer cell line (MCF-7) was obtained from National centre for cell sciences, Pune, India. Cells were maintained in Dulbecco's Modified Eagle's Medium (DMEM) containing 10\% (v/v) fetal bovine serum (FBS) and incubated at $37^{\circ} \mathrm{C}$ of $5 \%$ $\mathrm{CO} 2$. Streptomycin and penicillin $(100 \mu \mathrm{g} / \mathrm{ml})$ was used to avoid contamination.

\section{Anticancer analysis by MTT assay}

The anticancer property of crude bacterial extract was done by 3-(4,5-dimethyl-2-thiazolyl)-2,5diphenyl--tetrazolium bromide (MTT) assay [18]. The cells were seeded in 96 well plates at a concentration of $1 \times 10^{5}$ cells/well. After $24 \mathrm{~h}$, cells were washed twice with $100 \mu \mathrm{l}$ of serum-free medium and starved for $60 \mathrm{~m}$ at $37^{\circ} \mathrm{C}$. After starvation, cells were treated with different concentrations of crude extract $(10-100 \mu \mathrm{g} / \mathrm{ml})$ and incubated for $24 \mathrm{~h}$. After the incubation period, the medium was aspirated and serum free medium containing MTT $(0.5 \mathrm{mg} / \mathrm{ml})$ was added and incubated for $4 \mathrm{~h}$ at $37^{\circ} \mathrm{C}$ in a $\mathrm{CO} 2$ incubator. After incubation MTT containing medium was discarded and the cells were washed with PBS $(200 \mu \mathrm{l})$. The insoluble formazan crystals were dissolved by adding $100 \mu$ l of DMSO. 
Spectrophotometrical absorbance of the purple blue formazan dye was measured in a microplate reader at $570 \mathrm{~nm}$ (Biorad 680). The 50\% inhibitory concentration value (IC50) of the test compound was identified for treated cell line. The percentage of cell viability calculated using following formula

$$
\text { Percentage(\%)of cell viability }=\frac{\text { Test OD }}{\text { Control OD }} \times 100
$$

\section{Gas Chromatography Mass Spectrometry (GC-MS) analysis}

The ethyl acetate extract of the Bacillus subtilis metabolite was analyzed by Gas Chromatography Mass Spectrometry (GC-MS) to identify the compounds present. GC-MS analysis was performed in Perkin-Elmer GC Clarus 500 system comprising an AOC-20i auto-sampler and a Gas Chromatograph interfaced to a Mass Spectrometer (GCMS) equipped with Elite-5MS (5\% diphenyl/95\% dimethyl poly siloxane) fused capillary column $(30 \times$ $0.25 \mu \mathrm{m}$ ID $\times 0.25 \mu \mathrm{m}$ df). After analysis, the compounds were identified by matching with the known compound library.

\section{Molecular Docking Analysis Preparation of protein}

The three-dimensional crystal structure of Human estrogen receptor alpha (PDB: 3ERT) was downloaded in PDB format from the protein data bank (http://www.rcsb.org/pdb).

\section{Retrieval of ligands}

The ligands (bacterial compounds) were retrieved from the PubChem database in SDF (structure data format) (http://www.pubchem.ncbi.nlm.nih.gov) and then converted into the PDB format using online SMILE translator.

\section{Drug-likeness analysis}

The drug-likeness analysis of the compounds was done by based on the Lipinskiec s rule of five. As per "Rule of 5", the drug-like molecules have the number of hydrogen bond acceptors is not more than 10, number of hydrogen bond donors is not more than 5 , Partition coefficient $\log \mathrm{P}$ less than 5, molecular mass less than 500 daltons and number of violations not more than 2 [19].

\section{Docking analysis}

Molecular docking was carried out using AutoDock 4.2.6 software with their standard protocols and the visualization was done by Discovery studio 4.0.

\section{Statistical Analysis}

The results were expressed as mean \pm SD obtained from triplicates. Values were statistically significant $(\mathrm{P} \leq 0.05)$. The statistical analysis was done using Graph pad prism7 software.

\section{RESULTS AND DISCUSSION Isolation of soil bacteria}

In the current investigation the bacterial strain was isolated from the soil samples collected from Nilgiri district, Western Ghats, Tamilnadu, India. Many scientists have chosen soil is a primary site of the isolation of novel antibiotics producing bacteria [20, 21]. Similary, Islam et al. [22] reported several bacterial communities isolated from the soil samples of Western Ghats, which produce efficient bioactive compounds.

\section{Molecular identification of the bacterial isolate}

The molecular identification method could be used to identify the organism at the species level. The isolated bacterial strain was identified as Bacillus subtilis based on the 16S rRNA analysis and the strain showed 99\% similarity with Bacillus subtilis (NR102783) of the NCBI Gene bank data. The quality of the DNA isolated was checked using agarose gel electrophoresis. The gels were visualized in a UV transilluminator (Genei) and the image was captured under UV light using Gel documentation system (BioRad). The molecular standard used was a 2-log DNA ladder (NEB). The gels were visualized in a UV transilluminator (Genei) and the image was captured under UV light using Gel documentation system (Figure - 1). The obtained gene sequence was analyzed using BLAST software in GenBank website and the phylogenetic tree were constructed using Mega blast software (Figure- 2). The nucleotide sequence of Bacillus subtilis has been deposited in the NCBI GenBank database with the accession number MH198042. This result provided strong support to earlier studies which have already proved Bacillus species as the most predominant bacteria found in soil $[23,24]$.

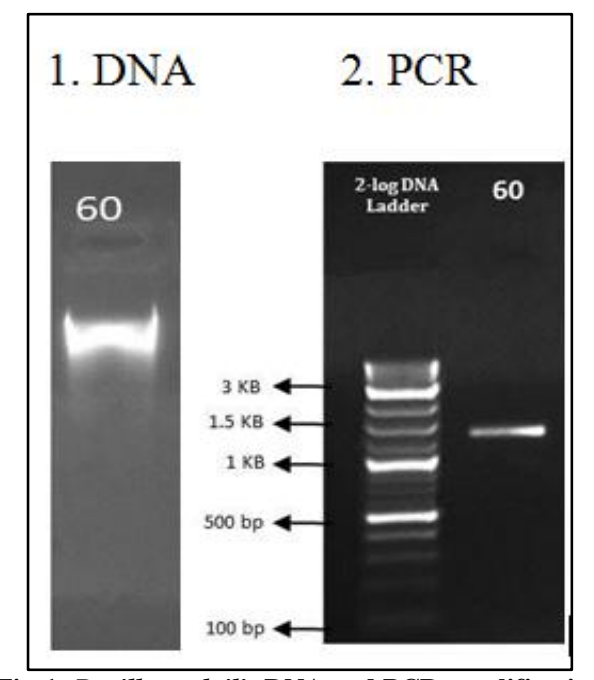

Fig-1: Bacillus subtilis DNA and PCR amplification 


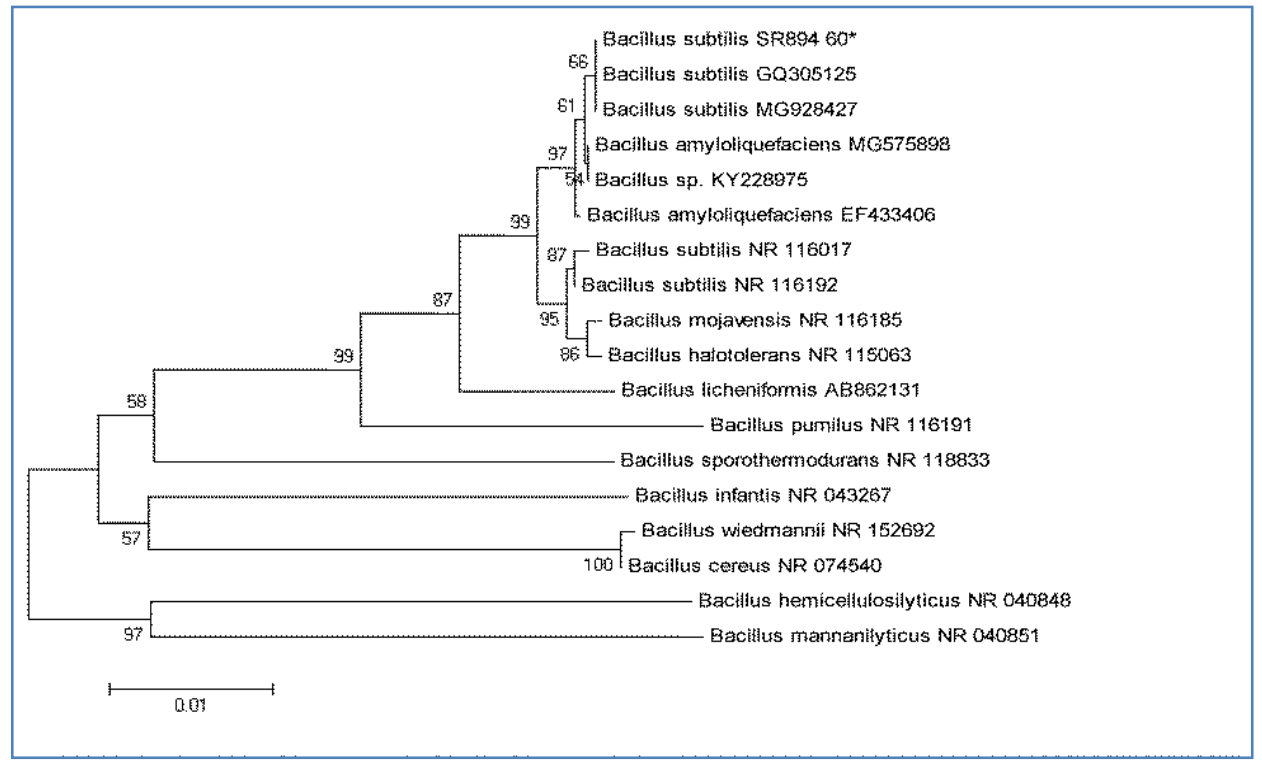

Fig-2: Phylogenetic tree of Bacillus subtilis

\section{Anticancer analysis}

The anticancer analysis of different concentrations (10 to $100 \mu \mathrm{g} / \mathrm{ml}$ ) of crude extract of Bacillus subtilis (MH198042) were tested against the breast cancer cell line (MCF-7) by MTT assay. The result showed $100 \mu \mathrm{g} / \mathrm{ml}$ concentration of the crude extract showed maximum anticancer activity against breast cancer cell line with the $\mathrm{IC}_{50}$ value of $100 \mu \mathrm{g} / \mathrm{ml}$ (Figure- 3 and Table- 1). The standard anticancer compound 5- Fluorouracil showed $\mathrm{IC}_{50}$ value of $25.63 \mu \mathrm{g} / \mathrm{ml}$ against the breast cancer cell line. Seerangaraj et al. [25] reported, the crude extract of Bacillus subtilis SVSK5 showed strong anticancer activity against breast cancer cell line (MCF-7) with the $\mathrm{IC}_{50}$ value of $150 \mu \mathrm{g} / \mathrm{ml}$ by MTT assay. In the present study, the crude extract of Bacillus subtilis (MH198042) showed strong activity against breast cancer cell line, when compared with the crude extract of Bacillus subtilis SVSK5 isolated from Oreochromis mossambicus and Labeo rohita. Similarly, Ramasubburayan et al. [26] reported crude extract of Bacillus subtilis subsp. subtilis RG, isolated from the rhizospheric soil of a mangrove plant species,
Excoecaria agallocha at South east coast of India, showed significant anticancer activity against human breast cancer (MCF-7) cell line with the $\mathrm{IC}_{50}$ value was $46.64 \pm 0.79 \mu \mathrm{g} / \mathrm{ml}$ as determined through MTT assay. Further, Aboul-Ela et al., [27] reported crude extracts of Bacillus subtilis strain FS05, isolated from Red sea sponge Amphimedon ochracea, showed potential anticancer activity against MCF-7 (breast carcinoma) with an $\mathrm{IC}_{50}$ of $5.5 \mu \mathrm{g} / \mathrm{ml}$ by MTT assay.

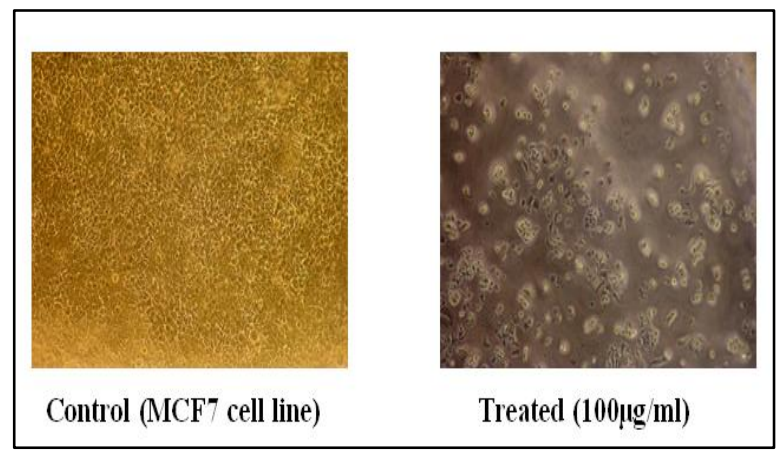

Fig-3: Anticancer analysis of crude extract of Bacillus subtilis

Table-1: Anticancer analysis of crude extract of Bacillus subtilis (MH198042) against breast cancer cell line (MCF-7)

\begin{tabular}{|c|c|c|}
\hline S.No. & Concentrations of the crude extract $(\boldsymbol{\mu g} / \mathbf{m l})$ & Percentage $(\boldsymbol{\%})$ of viability \\
\hline 1 & 10 & $94.02 \pm 0.06$ \\
\hline 2 & 20 & $88.44 \pm 0.12$ \\
\hline 3 & 30 & $83.02 \pm 0.56$ \\
\hline 4 & 40 & $76.02 \pm 0.80$ \\
\hline 5 & 50 & $71.64 \pm 0.26$ \\
\hline 6 & 60 & $63.31 \pm 0.39$ \\
\hline 7 & 70 & $60.74 \pm 0.35$ \\
\hline 8 & 80 & $55.02 \pm 0.36$ \\
\hline 9 & 90 & $48.11 \pm 0.56$ \\
\hline 10 & 100 & $36.80 \pm 0.52$ \\
\hline & IC $_{\mathbf{5 0}}$ Value & $\mathbf{1 0 0} \boldsymbol{\mu g} / \mathbf{m l}$ \\
\hline
\end{tabular}




\section{GC-MS analysis of crude extract of Bacillus subtilis}

GC-MS chromatogram of the ethyl acetate extract Bacillus subtilis (MH198042) showed 26 peaks indicating the presence of twenty six different compounds in the crude extract (Figure- 4). On comparison of the mass spectra of the constituents with the NIST library the twenty six bacterial compounds were characterized and identified (Table- 2). Among the twenty six compounds, the compound Cetene is the major peak compound found in the crude extract of Bacillus subtilis (MH198042) with the retention time of 13.61, followed by Phenol 2, 4-bis (1,1-dimethylethyl) with the retention time of 12.58. Recently, Phuong et al. [28] reported GC-MS analysis of ethyl acetate extract of Bacillus subtilis HD16b showed eight bioactive compounds. Additionally, Weiwei Liu et al. [29] reported the soil Bacillus subtilis G8 showed thirty bioactive compounds by GC-MS analysis.

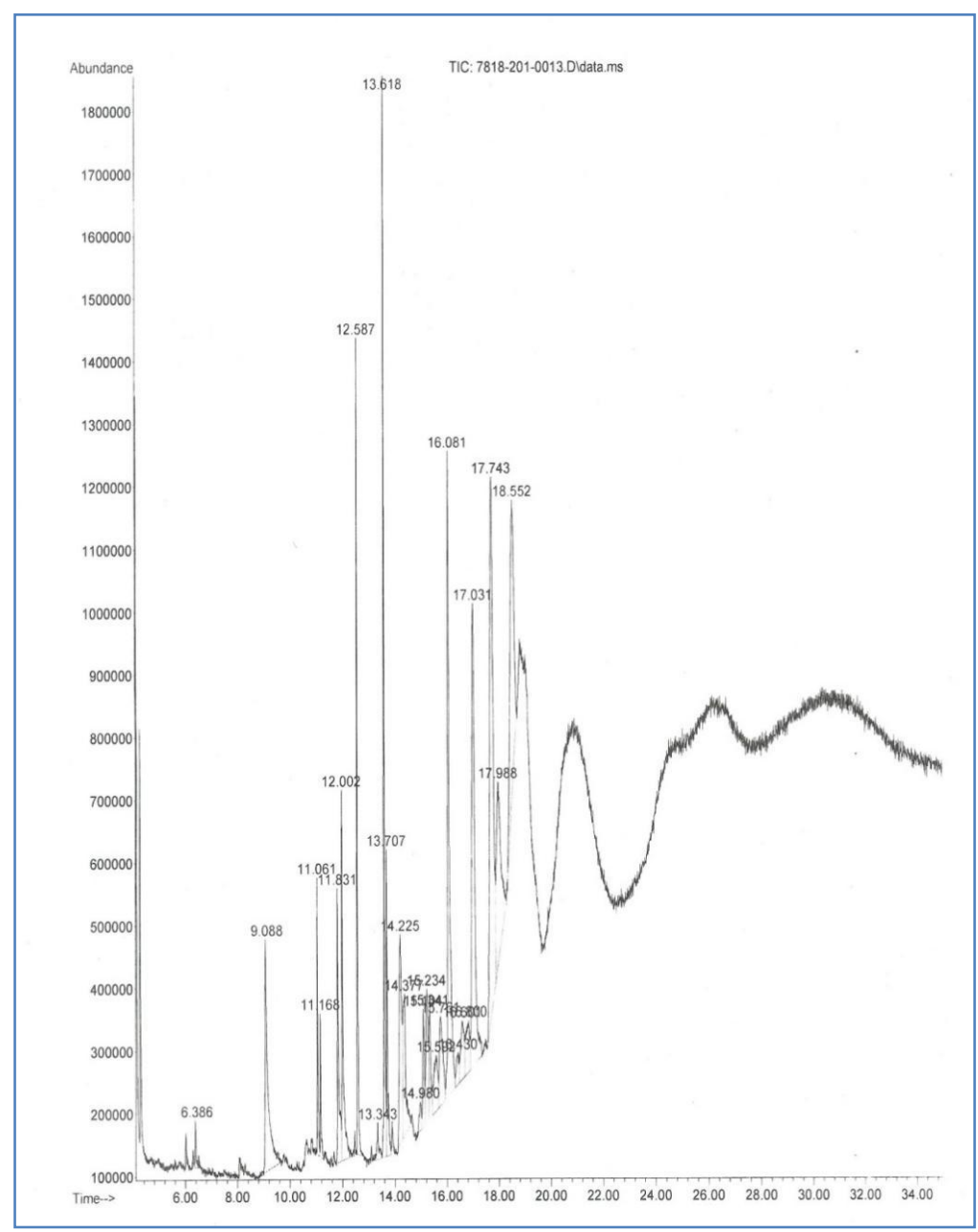

Fig-4: GC-MS chromatogram of crude extract of Bacillus subtilis (MH198042)

Table-2: Bioactive compounds identified from ethyl acetate extract of Bacillus subtilis by GC-MS analysis

\begin{tabular}{|c|l|l|l|l|l|}
\hline S.No. & RT & Compounds Name & $\begin{array}{l}\text { Molecular } \\
\text { Formula }\end{array}$ & $\begin{array}{l}\text { Molecular } \\
\text { Weight }\end{array}$ & $\begin{array}{l}\text { Peak } \\
\text { Area }\end{array}$ \\
\hline 1 & 6.38 & Pyrazine, tetramethyl- & $\mathrm{C}_{8} \mathrm{H}_{12} \mathrm{~N}_{2}$ & 136.198 & 0.35 \\
\hline 2 & 9.08 & Benzeneacetic acid & $\mathrm{C}_{8} \mathrm{H}_{8} \mathrm{O}_{2}$ & 136.15 & 5.06 \\
\hline 3 & 11.06 & 5-Tetradecene, (z)- & $\mathrm{C}_{14} \mathrm{H}_{28}$ & 196.378 & 1.45 \\
\hline 4 & 11.16 & Tetradecane & $\mathrm{C}_{14} \mathrm{H}_{30}$ & 198.394 & 0.81 \\
\hline 5 & 11.83 & Phosphine, methyl (1-methylethyl) phenyl- & $\mathrm{C}_{10} \mathrm{H}_{15} \mathrm{P}$ & 166.204 & 2.73 \\
\hline 6 & 12.00 & Cyclohexanone & $\mathrm{C}_{6} \mathrm{H}_{10} \mathrm{O}$ & 98.145 & 3.85 \\
\hline 7 & 12.58 & Phenol, 2,4-bis (1,1-dimethylethyl) & $\mathrm{C}_{14} \mathrm{H}_{22} \mathrm{O}$ & 206.329 & 4.28 \\
\hline 8 & 13.34 & Benzenemethanol, 2- (2-aminopropoxy)-3-methyl- & $\mathrm{C}_{11} \mathrm{H}_{17} \mathrm{NO}_{2}$ & 195.262 & 0.54 \\
\hline 9 & 13.61 & Cetene & $\mathrm{C}_{16} \mathrm{H}_{32}$ & 224.432 & 6.84 \\
\hline 10 & 13.70 & Hexadecane & $\mathrm{C}_{16} \mathrm{H}_{34}$ & 226.448 & 2.34 \\
\hline 11 & 14.22 & o-Acetylphenetidine & $\mathrm{C}_{10} \mathrm{H}_{13} \mathrm{NO}_{2}$ & 179.219 & 4.01 \\
\hline 12 & 14.37 & Benzene, 1-ethoxy-4-isothiocyanato & $\mathrm{C}_{9} \mathrm{H}_{9} \mathrm{NOS}_{2}$ & 179.237 & 3.33 \\
\hline 13 & 14.98 & p-Hydroxyamphetamine & $\mathrm{C}_{9} \mathrm{H}_{13} \mathrm{NO}_{2}$ & 151.209 & 0.46 \\
\hline 14 & 15.10 & 1-n- Hexyladamantane & $\mathrm{C}_{6} \mathrm{H}_{28}$ & 220.4 & 1.41 \\
\hline
\end{tabular}




\begin{tabular}{|c|c|c|c|c|c|}
\hline 15 & 15.23 & Acetamide, N-(3-methylphenyl) & $\mathrm{C}_{9} \mathrm{H}_{11} \mathrm{O}$ & 149.193 & 2.38 \\
\hline 16 & 15.34 & Benzaldehyde diethyl acetal & $\mathrm{C}_{11} \mathrm{H}_{16} \mathrm{O}_{2}$ & 180.247 & 1.56 \\
\hline 17 & 15.59 & Tricyclo[4.3.1.1(3,8)] undecan-1- amine & $\mathrm{C}_{11} \mathrm{H}_{19} \mathrm{~N}$ & 165.28 & 1.81 \\
\hline 18 & 15.75 & Phenol, 4-(1,1-dimethylpropyl)- & $\mathrm{C}_{11} \mathrm{H}_{16} \mathrm{O}$ & 164.248 & 2.40 \\
\hline 19 & 16.08 & E-15-Heptadecenal & $\mathrm{C}_{17} \mathrm{H}_{32} \mathrm{O}$ & 252.442 & 10.07 \\
\hline 20 & 16.43 & Metaraminol & $\mathrm{C}_{9} \mathrm{H}_{13} \mathrm{NO}_{2}$ & 167.208 & 0.70 \\
\hline 21 & 16.60 & Methylpent-4-enylamine & $\mathrm{C}_{6} \mathrm{H}_{13} \mathrm{~N}$ & 99.177 & 1.56 \\
\hline 22 & 16.79 & Acetamide, N-(alpha-methylphenethyl)- & $\mathrm{C}_{11} \mathrm{H}_{15} \mathrm{NO}$ & 177.247 & 1.62 \\
\hline 23 & 17.03 & 1,2-Benzenedicarboxylic acid, bis(2-methylpropyl) ester & $\mathrm{C}_{16} \mathrm{H}_{22} \mathrm{O}_{4}$ & 278.348 & 10.45 \\
\hline 24 & 17.74 & 1,2-Benzenedicarboxylic acid, butyl cyclohexyl ester & $\mathrm{C}_{18} \mathrm{H}_{24} \mathrm{O}_{4}$ & 304.386 & 14.72 \\
\hline 25 & 17.98 & 1,2-Benzenedicarboxylic acid, butyl octyl ester & $\mathrm{C}_{20} \mathrm{H}_{30} \mathrm{O}_{4}$ & 334.456 & 6.37 \\
\hline 26 & 18.55 & 2- (Nonyloxycarbonyl) benzoic acid & $\mathrm{C}_{17} \mathrm{H}_{24} \mathrm{O}_{4}$ & 292.375 & 8.93 \\
\hline
\end{tabular}

\section{Molecular docking analysis \\ Drug-likeness analysis}

Assessment of drug-likeness properties of identified compounds from Bacillus subtilis (MH198042) were tested for Lipinski"es rule of five.
The result showed all the twenty six compounds can satisfy Lipinski rule (Table -3). Hence, all the twenty six compounds were selected for molecular docking analysis against breast cancer protein Estrogen receptor alpha $(\mathrm{ER} \alpha)$.

Table-3: Drug-likeness analysis of bioactive compounds of Bacillus subtilis (MH198042) by Lipinski's rule of five (RO5)

\begin{tabular}{|c|l|c|c|c|c|c|}
\hline S.No. & Compounds Name & $\begin{array}{c}\text { MW(<500) } \\
\text { Da }\end{array}$ & $\begin{array}{c}\text { Log P } \\
(<\mathbf{5})\end{array}$ & $\begin{array}{c}\text { HBA } \\
(<\mathbf{1 0})\end{array}$ & $\begin{array}{c}\text { HBD } \\
(<\mathbf{5})\end{array}$ & $\begin{array}{c}\text { No. of } \\
\text { violations }\end{array}$ \\
\hline 1 & Pyrazine, tetramethyl- & 136.19 & 0.55 & 2 & 0 & 0 \\
\hline 2 & Benzeneacetic acid & 136.15 & 1.66 & 2 & 1 & 0 \\
\hline 3 & 5-Tetradecene, (z)- & 196.37 & 5.79 & 0 & 0 & 1 \\
\hline 4 & Tetradecane & 198.39 & 5.93 & 0 & 0 & 1 \\
\hline 5 & Phosphine, methyl (1-methylethyl) phenyl- & 166.2 & 3.56 & 0 & 0 & 0 \\
\hline 6 & Cyclohexanone & 98.14 & 1 & 1 & 0 & 0 \\
\hline 7 & Phenol, 2,4-bis (1,1-dimethylethyl) & 206.32 & 3.87 & 1 & 1 & 0 \\
\hline 8 & Benzenemethanol, 2- (2-aminopropoxy)-3-methyl- & 195.26 & 1.24 & 3 & 2 & 0 \\
\hline 9 & Cetene & 224.43 & 6.29 & 0 & 0 & 1 \\
\hline 10 & Hexadecane & 226.44 & 6.44 & 0 & 0 & 1 \\
\hline 11 & o-Acetylphenetidine & 179.21 & 1.54 & 2 & 1 & 0 \\
\hline 12 & Benzene, 1-ethoxy-4-isothiocyanato & 179.23 & 3.20 & 2 & 0 & 0 \\
\hline 13 & p-Hydroxyamphetamine & 151.21 & 1.53 & 2 & 2 & 0 \\
\hline 14 & 1-n- Hexyladamantane & 220.39 & 6.04 & 0 & 0 & 1 \\
\hline 15 & Acetamide, N-(3-methylphenyl) & 149.19 & 1.84 & 1 & 1 & 0 \\
\hline 16 & Benzaldehyde diethyl acetal & 180.24 & 2.53 & 2 & 0 & 0 \\
\hline 17 & Tricyclo[4.3.1.1(3,8)] undecan-1- amine & 165.28 & 2.74 & 1 & 1 & 0 \\
\hline 18 & Phenol, 4-(1,1-dimethylpropyl)- & 164.24 & 3.05 & 1 & 1 & 0 \\
\hline 19 & E-15-Heptadecenal & 252.44 & 4.44 & 1 & 0 & 1 \\
\hline 20 & Metaraminol & 167.21 & 0.65 & 3 & 3 & 0 \\
\hline 21 & Methylpent-4-enylamine & 99.17 & 1.39 & 1 & 1 & 0 \\
\hline 22 & Acetamide, N-(alpha-methylphenethyl)- & 177.24 & 2.17 & 1 & 1 & 0 \\
\hline 23 & 1,2-Benzenedicarboxylic acid, bis(2-methylpropyl) ester & 278.34 & 3.43 & 4 & 0 & 0 \\
\hline 24 & 1,2-Benzenedicarboxylic acid, butyl cyclohexyl ester & 304.38 & 3.52 & 4 & 0 & 0 \\
\hline 25 & 1,2-Benzenedicarboxylic acid, butyl octyl ester & 334.45 & 4.37 & 4 & 0 & 1 \\
\hline 26 & 2- (Nonyloxycarbonyl) benzoic acid & 292.37 & 3.67 & 4 & 1 & 0 \\
\hline & & & & \\
\hline
\end{tabular}

\section{Molecular docking analysis of bioactive compounds against targeted breast cancer protein Estrogen receptor alpha (PDB id: 3ERT)}

Breast cancer is known as a death sentence and second major cause of death in world. Ratio of breast cancer in is one in nine in case of women [30]. Main cause of breast cancer is overexpression of estrogen receptor alpha [31]. Therefore ER- $\alpha$ is used as a target for prevention of breast cancer. In the present investigation, all the twenty six compounds were screened against the breast cancer protein Estrogen receptor alpha (PDB id: 3ERT). Among the twenty six compounds, the compound Metaraminol showed maximum docking score $-7.27 \mathrm{Kcal} / \mathrm{mol}$ (Figure-5) with the targeted protein followed by 1-nHexyladamantane and Tricyclo[4.3.1.1(3,8)] undecan1 - amine with the docking scores of -7.19 and -7.01 $\mathrm{Kcal} / \mathrm{mol}$ respectively (Table- 4). So, these compounds may be reason for the in vitro anticancer analysis of crude extract of Bacillus subtilis (MH198042) against breast cancer (MCF-7) cell line. Similarly, Ravi et al. [32] reported the compound gancidin W isolated from the bacterium Streptomyces paradoxus VITALK03. The compound showed good docking score -7.55 
$\mathrm{Kcal} / \mathrm{mol}$ against the targeted breast cancer protein ERas of pERK pathway. Additionally, Shanta et al., [33] reported to screen the five bioactive compounds namely 1,1-diphenyl-2- picrylhydrazyl, quercetin, kaempferol, kaempferol 3-bita-D-glucopyranoside and isocorilagin against breast cancer protein estrogen receptor alpha (ER- $\alpha)$ (PDB id: 3ERT). Among the five compounds, the compound isocorilagin showed maximum docking score $-7.90 \mathrm{Kcal} / \mathrm{mol}$ against the targeted protein.

Table-4: In silico docking analysis of bioactive compounds of bacillus subtilis (MH198042) against breast cancer protein Estrogen receptor alpha (PDB id: 3ERT))

\begin{tabular}{|c|c|c|c|c|}
\hline S.No & Compounds Name & $\begin{array}{c}\text { Binding } \\
\text { Energy } \\
\text { (Kcal/mol) }\end{array}$ & Interacting Aminoacid residues & $\begin{array}{l}\text { RMSD } \\
(\AA) \\
\text { Value } \\
\end{array}$ \\
\hline 1 & Pyrazine, tetramethyl- & -4.99 & $\begin{array}{l}\text { Pro324, Glu353, His356, Met357, Trp360, Ile386, Leu387, Gly390, } \\
\text { Arg394, Lys449 }\end{array}$ & 0.09 \\
\hline 2 & Benzeneacetic acid & -4.57 & $\begin{array}{l}\text { Pro324, Glu353, Met357, Ile386, Leu387, Ile389, Gly390, Arg394, } \\
\text { Phe445, Lys449 }\end{array}$ & 1.99 \\
\hline 3 & 5-Tetradecene, $(\mathrm{z})$ - & -5.05 & $\begin{array}{l}\text { Glu323, Pro324, Ile326, Glu353, Met357, Trp360, Ile386, Leu387, } \\
\text { Gly390, Leu391, Trp393, Arg394, Phe445, Lys449 }\end{array}$ & 0.99 \\
\hline 4 & Tetradecane & -4.78 & $\begin{array}{l}\text { Pro324, Pro325, Ile326, Glu353, Met357, Ile386, Leu387, Gly390, } \\
\text { Trp393, Arg394, Phe445, Lys449 }\end{array}$ & 0.98 \\
\hline 5 & $\begin{array}{l}\text { Phosphine, methyl (1- } \\
\text { methylethyl) phenyl- }\end{array}$ & -5.31 & $\begin{array}{l}\text { Pro324, Glu353, His356, Met357, Ile386, Leu387, Gly390, Leu391, } \\
\text { Arg394, Phe445, Lys449 }\end{array}$ & 0.04 \\
\hline 6 & Cyclohexanone & -4.79 & Pro324, Glu353m, His356, Met357, Ile386, Leu387, Lys449 & 0.01 \\
\hline 7 & $\begin{array}{l}\text { Phenol, 2,4-bis }(1,1- \\
\text { dimethylethyl) }\end{array}$ & -6.31 & $\begin{array}{l}\text { Glu323, Pro324, Pro325, Ile326, Glu353, Ile386, Leu387, Gly390, } \\
\text { Trp393, Arg394, Phe445, Lys449 }\end{array}$ & 0.06 \\
\hline 8 & $\begin{array}{l}\text { Benzenemethanol, 2- (2- } \\
\text { aminopropoxy)-3-methyl- }\end{array}$ & -5.56 & $\begin{array}{l}\text { Glu323, Pro324, Glu353, Met357, Trp360, Ile386, Leu387, Gly390, } \\
\text { Leu391, Arg394, Phe445, Lys449 }\end{array}$ & 1.97 \\
\hline 9 & Cetene & -4.79 & $\begin{array}{l}\text { Glu323, Pro324, Pro325, Ile326, Glu353, Met357, Trp360, Ile386, } \\
\text { Leu387, Gly390, Trp393, Arg394, Phe445, Lys449 }\end{array}$ & 1.21 \\
\hline 10 & Hexadecane & -4.99 & $\begin{array}{l}\text { Glu323, Pro324, Pro325, Ile326, Glu353, Met357, Ile386, Leu387, } \\
\text { Gly390, Arg394, Phe445, Lys449 }\end{array}$ & 1.13 \\
\hline 11 & o-Acetylphenetidine & -5.56 & $\begin{array}{l}\text { Glu323, Pro324, Pro325, Glu353, Met357, Trp360, Ile386, Leu387, } \\
\text { Gly390, Arg394, Phe445, Lys449 }\end{array}$ & 0.08 \\
\hline 12 & $\begin{array}{l}\text { Benzene, 1-ethoxy-4- } \\
\text { isothiocyanato }\end{array}$ & -4.79 & $\begin{array}{l}\text { Pro324, Glu353, Met357, Trp360, Ile386, Leu387, Gly390, Leu391, } \\
\text { Arg394, Lys449 }\end{array}$ & 0.34 \\
\hline 13 & p-Hydroxyamphetamine & -5.54 & $\begin{array}{l}\text { Glu323, Pro324, Glu353, Ile386, Leu387, Gly390, Leu391, Trp393, } \\
\text { Arg394, Phe445, Lys449 }\end{array}$ & 1.83 \\
\hline 14 & 1-n- Hexyladamantane & -7.19 & $\begin{array}{l}\text { Glu323, Pro324, Pro325, Ile326, Met357, Trp360, Ile386, Leu387, } \\
\text { Gly390, Trp393, Arg394, Phe445, Lys449 }\end{array}$ & 0.57 \\
\hline 15 & $\begin{array}{l}\text { Acetamide, N-(3- } \\
\text { methylphenyl) }\end{array}$ & -5.14 & $\begin{array}{l}\text { Glu323, Pro324, Glu353, Met357, Ile386, Leu387, Gly390, Trp393, } \\
\text { Arg394, Phe445, Lys449 }\end{array}$ & 0.08 \\
\hline 16 & $\begin{array}{l}\text { Benzaldehyde diethyl } \\
\text { acetal }\end{array}$ & -4.96 & $\begin{array}{l}\text { Glu323, Pro324, Glu353, Met357, Ile386, Leu387, Gly390, Leu391, } \\
\text { Trp393, Arg394, Phe445, Lys449 }\end{array}$ & 1.39 \\
\hline 17 & $\begin{array}{l}\text { Tricyclo[4.3.1.1(3,8)] } \\
\text { undecan-1- amine }\end{array}$ & -7.01 & $\begin{array}{l}\text { Pro324, Pro325, Glu353, Ile386, Leu387, Gly390, Leu391,Arg394, } \\
\text { Lys449 }\end{array}$ & 0.03 \\
\hline 18 & $\begin{array}{l}\text { Phenol, 4-(1,1- } \\
\text { dimethylpropyl)- }\end{array}$ & -5.31 & $\begin{array}{l}\text { Glu323, Pro324, Pro325, Ile326, Glu353, Met357, Ile386, Leu387, } \\
\text { Gly390, Leu391, Arg394, Lys449 }\end{array}$ & 0.11 \\
\hline 19 & E-15-Heptadecenal & -4.97 & $\begin{array}{l}\text { Glu323, Pro324, Pro325, Ile326, Glu353, Met357,Trp360, Ile386, } \\
\text { Leu387, Gly390, Trp393, Arg394, Phe445, Lys449 }\end{array}$ & 1.81 \\
\hline 20 & Metaraminol & -7.27 & $\begin{array}{l}\text { Glu323, Pro324, Pro325, Glu353, Ile386, Leu387, Gly390, Leu391, } \\
\text { Arg394, Phe445, Lys449 }\end{array}$ & 0.10 \\
\hline 21 & Methylpent-4-enylamine & -3.87 & Pro324, Glu353, Met357, Trp360, Ile386, Leu387, Arg394, Lys449 & 0.47 \\
\hline 22 & $\begin{array}{l}\text { Acetamide, N-(alpha- } \\
\text { methylphenethyl)- }\end{array}$ & -5.81 & $\begin{array}{l}\text { Glu323, Pro324, Glu353, His356, Met357, Ile386, Leu387, Gly390, } \\
\text { Leu391, Arg394, Phe445, Lys449 }\end{array}$ & 0.30 \\
\hline 23 & $\begin{array}{l}\text { 1,2-Benzenedicarboxylic } \\
\text { acid, bis(2-methylpropyl) } \\
\text { ester }\end{array}$ & -5.47 & $\begin{array}{l}\text { Glu323, Pro324, Pro325, Ile326, Glu353, His356, Met357, Ile386, } \\
\text { Leu387, Gly390, Trp393, Arg394, Phe445, Lys449 }\end{array}$ & 1.55 \\
\hline 24 & $\begin{array}{l}\text { 1,2-Benzenedicarboxylic } \\
\text { acid, butyl cyclohexyl } \\
\text { ester }\end{array}$ & -6.61 & $\begin{array}{l}\text { Glu323, Pro324, Ile326, Glu353, Met357, Ile386, Leu387, Gly390, } \\
\text { Leu391, Trp393, Arg394, Lys449 }\end{array}$ & 0.65 \\
\hline 25 & $\begin{array}{l}\text { 1,2-Benzenedicarboxylic } \\
\text { acid, butyl octyl ester }\end{array}$ & -5.74 & $\begin{array}{l}\text { Pro324, Glu353, Met357, Leu384, Ile386, Leu387, Met388, Gly390, } \\
\text { Leu391, Arg394, Leu428, Phe445, Lys449 }\end{array}$ & 1.97 \\
\hline 26 & $\begin{array}{l}\text { 2- (Nonyloxycarbonyl) } \\
\text { benzoic acid }\end{array}$ & -4.50 & $\begin{array}{l}\text { Glu323, Pro324, Pro325, Ile326, Glu353, Met357, Ile386, Leu387, } \\
\text { Met388, Ile389, Gly390, Leu391, Trp393, Arg394, Phe445, Lys449 }\end{array}$ & 1.34 \\
\hline 27 & $\begin{array}{l}\text { 5-Fluorouracil (Standard } \\
\text { compound) }\end{array}$ & -4.19 & $\begin{array}{l}\text { Glu323,Pro324,Ile326, Glu353,Met357Ile386,Leu387,Gly390,Leu391, } \\
\text { Trp393Arg394, Phe445, Lys449 }\end{array}$ & 0.82 \\
\hline
\end{tabular}




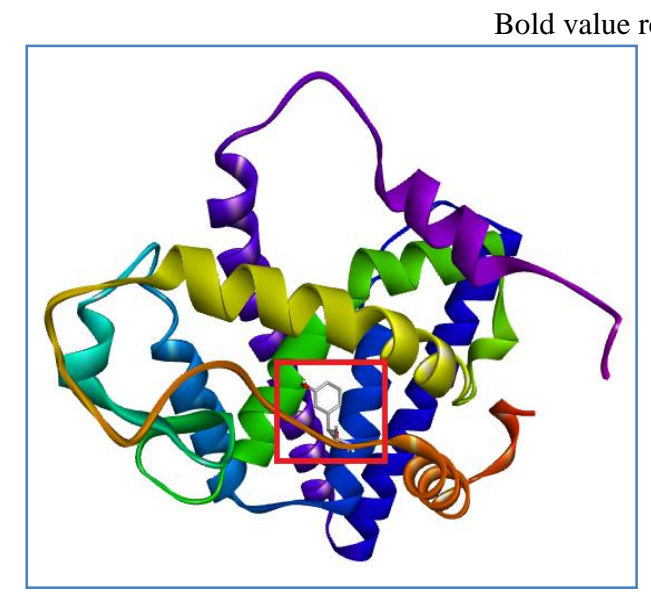

Interaction of compound with protein

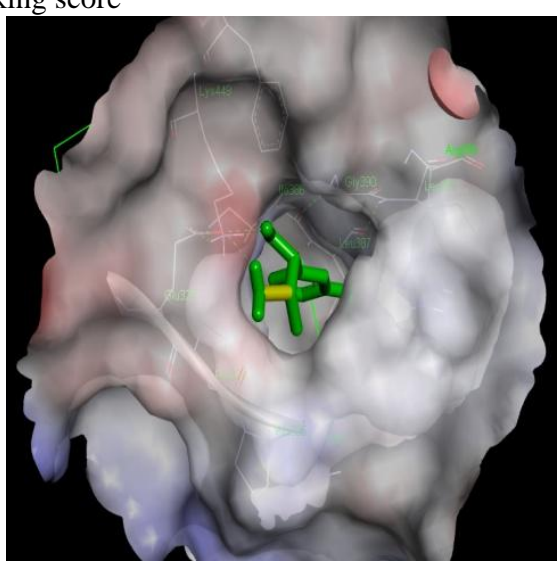

Compound docked with protein cavity

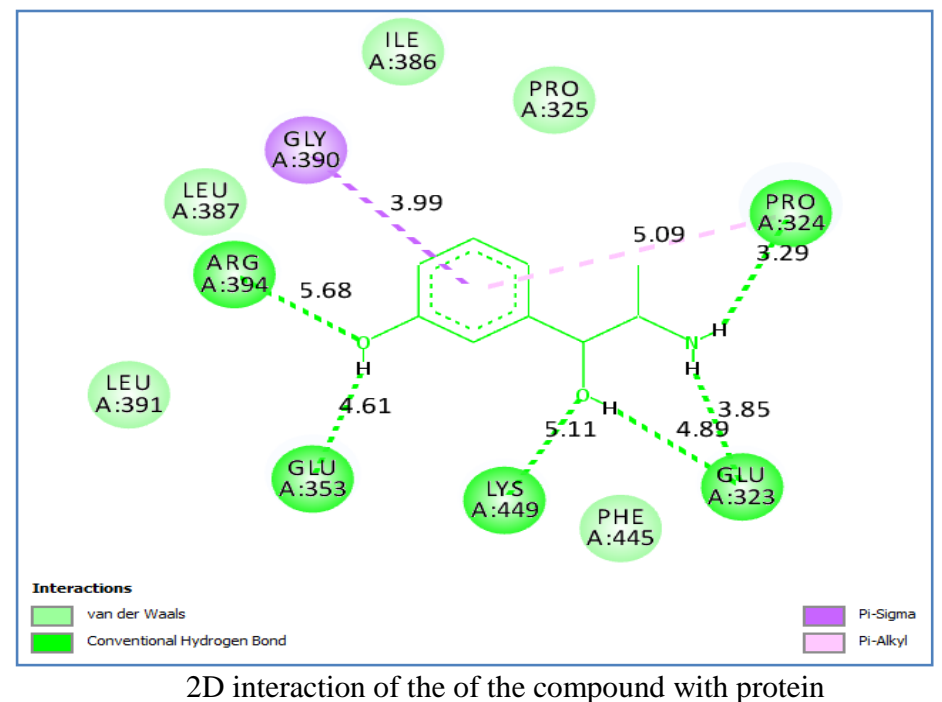

Fig-5: Interaction of the compound Metaraminol with the targetd breast cancer protein estrogen receptor alpha (PDB id: 3ERT)

\section{CONCLUSION}

The current study showed that bioactive metabolites obtained from Bacillus subtilis (MH198042) showed in vitro anticancer activity against breast cancer (MCF-7). The in silico analysis of the bioactive compounds showed good docking scores against the targeted breast cancer protein Estrogen receptor alpha. Among all the compounds, Metaraminol showed best docking score towards estrogen receptor alpha. Hence, the further study should focuse on exploration of the functions and molecular mechanisms of the compound which will facilitate a better understanding for the control of breast cancer and in development of anticancer drugs.

\section{ACKNOWLEDGMENTS}

Authors thank the Management of RKM Vivekananda College (Autonomous) for providing all the necessary facilities and encouragement.

\section{REFERENCES}

1. Coleman, M. P., Quaresma, M., Berrino, F., Lutz, J. M., De Angelis, R., Capocaccia, R., Baili, P.,
Rachet, B., Gatta, G., \& Hakulinen, T.(2008). Cancer survival in five continents: A worldwide population-based study (concord). Lancet Oncology, 9, 730-756.

2. Mijatovic, T., Van Quaquebeke, E., Delest, B., Debeir, O., Darro, F., \& Kiss, R., Cardiotonic. (2007). Steroids on the road to anti-cancer therapy. Biochimica et Biophysica Acta. 1776, 32-57.

3. Hafiz, H. (2017). Epigenetic mechanisms of tamoxifen resistance in luminal breast cancer. Diseases, 5(3), 1-11.

4. Tyc, O., Song, C., Dickschat, J. S., Vos, M., \& Garbeva, P.(2017). The ecological role of volatile and soluble secondary metabolites produced by soil bacteria. Trends in Microbiology, 25, 280-292.

5. Lin, Y. T., Whitman, W. B., Coleman, D. C., Jien, S. H., \& Chiu, Y. (2017). Cedar and bamboo plantations alter structure and diversity of the soil bacterial community from a hardwood forest in subtropical mountain. Applied Soil Ecology, 112, 28-33.

6. Liu. X., Zhang, B., Zhao, W., Wang, L., Xie, D., Huo, W., Wu, Y., \& Zhan, J.(2017). Comparative 
effects of sulfuric and nitric acid rain on litter decomposition and soil microbial community in subtropical plantation of Yangtze River Delta region. Science of the Total Environment, 601-602, 669.

7. Delgadobaquerizo, M., Reich, P. B., Khachane, A. N., Campbell, C. D., Thomas, N., Freitag, T. E., Al-Soud, W. A., Sorensen, S., Bardgett, R. D., \& Singh, B. K.(2016). It is elemental: soil nutrient stoichiometry drives bacterial diversity. Environmental Microbiology, 19, 1176.

8. Wardle, D. A. (2006). The influence of biotic interactions on soil biodiversity. Ecology Letters, 9 , 870.

9. Zechmeister Boltenstern, S., Keiblinger, K. M., Mooshammer, M., Penuelas, J., Richter, A., Sardans, J., \& Wanek, W. (2016). The application of ecological stoichiometry to plant-microbial-soil organic matter transformations. Ecological Monographs, 85, 133-155.

10. Rocheli, D. S., Adriana, A., \& Passaglia, L. M. P.(2015). Plant growth-promoting bacteria as inoculants in agricultural soils. Genetics and Molecular Biology, 38, 401-419.

11. Alexander, M.(1977). Introduction to soil microbiology. (2nd edition), John Wiley and Sons Inc, New York, USA.

12. Jeffrey, L. S. H.(2008). Isolation, characterization and identification of actinomycetes from agriculture soils at Semongok, Sarawak. African Journal of Biotechnology, 7(20), 59415.

13. Kuta, F. A.(2008). Antifungal effects of Calotropis Procera stem bank extract against Trichoplyton gypseun and Epiderinoplyton Flocosum. African Journal of Biotechnology, 7(13), 2116-2118.

14. Kim, Y. S., Balaraju, K., \& Jeon, Y. (2017). Biological characteristics of Bacillus amyloliquefaciens AK-0 and suppression of ginseng root-rot caused by Cylindrocarpon destructans. Journal of Applied Microbiology,122, 166-179.

15. Zhao, H. B., Shao, D. Y., Jiang, C. M., Shi, J. L., Li, Q., Huang, Q. S., Rajoka, M. S. R., Yang, H., \& Jin, M. L.(2017). Biological activity of lipopeptides from Bacillus. Applied Microbiology and Biotechnology, 101(15), 5951-596

16. Drummond, A. J., Ashton, B., Buxton, S., Cheung, M., Cooper, A., Duran, C., Heled, J., Kearse, M., Markowitz, S., Moir, R., Stones-Havas, S., Sturrock, S., Swidan, F., Thierer, T. and Wilson, A., Geneious v5.6, 2012, Available from http://www.geneious.com.

17. Tamura, K., Dudley, J., Nei, M., \& Kumar, S., MEGA4.(2007). Molecular Evolutionary Genetics Analysis (MEGA) software version 4.0. Molecular Biology and Evolution, 24, $1596 \mathrm{e} 9$.

18. Mosmann, T.(1983). Rapid colorimetric assay for cellular growth and survival: Application to proliferation and cytotoxicity assays. Journal of Immunological Methods, 65(1-2), 55-63.
19. Lipinski, C. A.(2004). Lead and drug-like compounds: the rule-of-five revolution. Drug Discovery Today Technologies, 1(4), 337-341.

20. Nike, A. R., Hassan, S. A., Ajijolakewu., \& Bosede. A. F.(2013). Soil screening for antibiotic producing microorganisms. Advances in Environmental Biology, 7, 7-11.

21. Yunus, F. N., Khalid, Z. Z., Rashid, F., Ashraf, A., Iqbal, M. N., \& Hussain, F.(2016). Isolation and screening of antibiotic producing bacteria from soil in Lahore city. PSM Microbiology, 1, 1-4.

22. Islam, M. R., Jeong, Y. T., Lee, Y. S., \& Song, C. H. (2012). Isolation and identification of antifungal compounds from Bacillus subtilis C9 inhibiting the growth of plant pathogenic fungi. Mycobiology, 40, 59-66.

23. Cavalcanti, M. A. D. Q., Oliveira, L. G. D., Fernandes, M. J. and Lima, D. M.(2006). Filamentous fungi isolated from soil in districts of the Xingo region, Brazil. Acta Botanica Brasilica, 20, 831-837.

24. Singh, A. P., Singh, R. B., \& Mishra, S.(2015). Studies on isolation and characterization of antibiotic producing microorganisms from industrial waste soil sample. Open Nutraceuticals Journal, 5, 169-173.

25. Seerangaraj, V., Kannan, S., Vijayakumar, U., Meganathan, B., Seerangaraj, V., Selvam, S. and Selvaraj, J. (2017). Isolation and characterization of bioactive compounds from Bacillus cereus and Bacillus subtilis from Oreochromis mossambicus and Labeo rohita. International Journal of Pharmaceutical Sciences Review and Research, 43(2), 71-77.

26. Ramasubburayan, R., Sumathi, S., Bercy, D. M., Immanuel, G., \& Palavesam, A. (2015). Antimicrobial, antioxidant and anticancer activities of mangrove associated bacterium Bacillus subtilis subsp. subtilis RG. Biocatalysis and Agricultural Biotechnology, 4(2), 158-165.

27. Aboul-Ela, H. M., Shreadah, M. A., AbdelMonem, N. M., Yakout, G. A., \& Soest R. W. M.(2012). Isolation, cytotoxic activity and phylogenetic analysis of Bacillus sp. bacteria associated with the red sea sponge Amphimedon ochracea. Advances in Bioscience and Biotechnology, 3(7), 815-823.

28. Phuong, T. V., Han, P. N. and Diep, C. N.(2018). Bioactive compounds from marine bacterium Bacillus subtilis strain HD16b by Gas Chromatography-Mass Spectrometry. The Pharmaceutical and Chemical Journal, 5(2), 110118

29. Weiwei, Liu., Wei M.U., Bingyu, Z., \& Feng, L. (2008). Antifungal activities and components of VOCs produced by Bacillus subtilis G8. Current Research in Bacteriology, 1(1), 28-34.

30. Naeem, M., Khan, N., Aman, Z., Nasir, A., Samad, A., \& Khattak, A.(2008). Pattern of breast cancer: Experience at lady reading hospital, Peshawar. 
Journal of Ayub Medical College Abbottabad, 20, 22-25.

31. Hayashi, S., Eguchi, H., Tanimoto, K., Yoshida, T., Omoto, Y., Inoue, A., Yoshida, N., \& Yamaguchi, Y.(2003). The expression and function of estrogen receptor alpha and beta in human breast cancer and its clinical application. Endocrine-Related Cancer, 10(2), 193-202.

32. Ravi, L., Ragunathan, A., \& Krishnan, K. (2017). Marine Streptomyces paradoxus VITALK03 derived gancidin $\mathrm{W}$ mediated cytotoxicity through
Ras-Raf-MEK-ERK signaling pathway. Indian Journal of Biotechnology, 16, 164-175.

33. Shanta, A., Nazim, U., Kazi Zahra, M., Tarannur Kabir, N., Fayejun, N., Shermin, A., Sahida, A., Sajal, C., Dipannita, C., \& Nasrin, A. (2018). In silico molecular docking approch of some selected isolated phytochemicals from Phyllanthus Emblic against breast cancer. Biomedical Journal of Scientific \& Technical Research, 10(2), MS.ID.001917. 